\title{
Crambe grain yield affected by compaction degrees of an Oxisol
}

\author{
Rendimento de grãos de crambe afetado por graus de compactação de um Latossolo \\ Rendimiento de grano de Crambe afectado por grados de compactación de un Oxisol
}

Recebido: 03/02/2022 | Revisado: 07/02/2022 | Aceito: 09/02/2022 | Publicado: 15/02/2022

\author{
Araceli Ciotti de Marins \\ ORCID: https://orcid.org/0000-0001-8932-7015 \\ Universidade Tecnológica Federal do Paraná, Brazil \\ E-mail: araceli@utfpr.edu.br \\ José Miguel Reichert \\ ORCID: https://orcid.org/0000-0001-9943-2898 \\ Universidade Federal de Santa Maria, Brazil \\ E-mail: reichert@ufsm.br \\ Deonir Secco \\ ORCID: https://orcid.org/0000-0002-3042-159X \\ Universidade Estadual do Oeste do Paraná, Brazil \\ E-mail: deonir.secco@unioeste.br \\ Doglas Bassegio \\ ORCID: https://orcid.org/0000-0001-6628-8594 \\ Universidade Estadual do Oeste do Paraná, Brazil \\ E-mail: doglas.bassegio@unioeste.br \\ Daniela Trentin Nava \\ ORCID: https://orcid.org/0000-0003-2131-3754 \\ Universidade Tecnológica Federal do Paraná, Brazil \\ E-mail:dnava@utfpr.edu.br
}

\begin{abstract}
Crambe is a new crop that produces oil used for biodiesel production. Soil compaction in a no-tillage (NT) system is one of the main challenges for sustainable grain production in soil clay. The objective of this study was to evaluate the effect of compaction degree on crambe grain yield over two years. The levels of artificial compaction were generated using a roller compactor $(0,1,3$, and 5 passes) under a NT system. The experimental design was a strip block, and soil density and crambe grain yield were evaluated. The passes of the roller increased the density from 0.98 to 1.24 $\mathrm{Mg} \mathrm{m}^{-3}$ in the $0-0.1 \mathrm{~m}$ layer, and 1.03 to $1.15 \mathrm{Mg} \mathrm{m}^{-3}$ in the $0.1-0.2 \mathrm{~m}$ layer. As a result, the compaction degree increased from $53 \%$ to $66 \%$ in the $0-0.1 \mathrm{~m}$ layer and $54 \%$ to $61 \%$ in the $0.1-0.2 \mathrm{~m}$ layer. Five passes of the roller compactor reduced the crambe grain yield by $41 \%$ and $9 \%$ in the first and second years, respectively, compared to the NT system without additional compaction. The crambe grain yield was reduced when the compaction degree reached $53 \%$; therefore, crambe is not suitable for compacted soils.
\end{abstract}

Keywords: Soil density; Soil structure; Energy crops.

\section{Resumo}

O crambe é uma nova cultura que produz óleo usado para produção de biodiesel. A compactação do solo em sistema plantio direto (PD) é um dos principais desafios para a produção sustentável de grãos em solos argilosos. O objetivo deste trabalho foi avaliar o efeito do grau de compactação na produtividade de grãos de crambe ao longo de dois anos. Os níveis de compactação artificial foram gerados usando um compactador de rolos $(0,1,3$ e 5 passes) em sistema de plantio direto. $\mathrm{O}$ delineamento experimental foi em faixas e foram avaliados a densidade do solo e a produtividade de grãos de crambe. Os passes do rolo aumentaram a densidade de 0,98 para $1,24 \mathrm{Mg} \mathrm{m}^{-3}$ na camada de $0-0,1 \mathrm{~m}$, e 1,03 para $1,15 \mathrm{Mg} \mathrm{m}^{-3}$ na camada de $0,1-0,2 \mathrm{~m}$. Como resultado, o grau de compactação aumentou de $53 \%$ para $66 \%$ na camada de $0-0,1 \mathrm{~m}$ e de $54 \%$ para $61 \%$ na camada de $0,1-0,2 \mathrm{~m}$. Cinco passadas do rolo compactador reduziram a produtividade de grãos de crambe em $41 \%$ e $9 \%$ no primeiro e segundo anos, respectivamente, em relação ao sistema plantio direto sem compactação adicional. O rendimento de grãos de crambe foi reduzido quando o grau de compactação atingiu 53\%; portanto, o crambe não é adequado para solos compactados.

Palavras-chave: Densidade do solo; Estrutura do solo; Culturas energéticas.

\section{Resumen}

Crambe es un nuevo cultivo que produce aceite usado para la producción de biodiesel. La compactación del suelo en sistema de labranza cero (PD) es uno de los principales desafíos para la producción sostenible de granos en suelos arcillosos. El objetivo de este trabajo fue evaluar el efecto del grado de compactación sobre el rendimiento de granos de crambe durante dos años. Los niveles de compactación artificial se generaron utilizando un compactador de rodillos $(0,1,3$ y 5 pasadas) en un sistema de labranza cero. El diseño experimental fue en franjas y se evaluó la densidad del suelo y el rendimiento de grano crambe. Los pases de rodillos aumentaron la densidad de 0,98 a 1,24 Mg 
$\mathrm{m}^{-3}$ en la capa de $0-0,1 \mathrm{~m}$, y de 1,03 a $1,15 \mathrm{Mg} \mathrm{m}^{-3}$ en la capa de $0,1-0,2 \mathrm{~m}$. Como resultado, el grado de compactación aumentó del $53 \%$ al $66 \%$ en la capa de 0 a 0,1 my del $54 \%$ al $61 \%$ en la capa de 0,1 a 0,2 m. Cinco pasadas de rodillos redujeron el rendimiento de grano crambe en un $41 \%$ y un $9 \%$ en el primer y segundo año, respectivamente, en comparación con el sistema de labranza cero sin compactación adicional. El rendimiento de grano de Crambe se redujo cuando el grado de compactación alcanzó el 53\%; por lo tanto, crambe no es adecuado para suelos compactados.

Palabras clave: Densidad del suelo; Estructura del suelo; Culturas energéticas.

\section{Introduction}

In Brazil, more than 32 million hectares of land is worked under a no-tillage (NT), and the main crops grown under this system are soy and corn (Peixoto et al., 2019). Under such conditions (zero tillage), soil compaction problems are common, resulting from external pressures of machines or animals, or the natural process of accommodation of soil particles (Hamza et al., 2005). Changes in soil structure caused by traffic decrease the volume of pores, limit the infiltration of water in the soil, reduce gas exchange and the availability of oxygen, and restrict the growth of the roots, reducing the development of the shoot and the grain yield (Queiroz-Voltan et al., 2000; Reichert et al., 2009); therefore, the effects of traffic on crop yields have been extensively studied (Suzuki et al., 2007; Secco et al., 2009; Mueller et al., 2010).

The compaction degree is used to characterize the relationship between compaction and crop growth (Collares et al., 2008). The compaction degree and crop yield have an indirect relationship, since the former changes soil physical properties directly linked to the growth of plants (Suzuki et al., 2007; Betioli Júnior et al., 2012; Tokura et al., 2021; Castro et al., 2021). Thus, the optimal compaction degree values for crops depend on the granulometric composition and soil structure (Suzuki et al., 2007; Andognini et al., 2020), and the magnitude of these values may vary over time depending on the climatic conditions, particularly the water availability and the crops involved (Hamza et al., 2005).

Despite the large amount of data on the yields of agricultural crops at different compaction levels, the effects of the compaction degree have not been extensively studied with crambe. The few studies that focused on crambe related individual properties to plant growth, particularly penetration resistance (Dias et al., 2015), but this is only one of the many affecting factors. The effect of the compaction degree on crop yield has been studied more extensively for other agricultural crops, such as soybean and corn (Santos et al., 2005; Suzuki et al., 2007; Bergamin et al., 2010). Suzuki et al. (2007) found that the optimum compaction degree for the soybean crop was $86 \%$, considering that a compaction degree lower than $80 \%$ may influence crop yields. The effect of compaction is mainly related to soil moisture, but is also dependent on the type of soil and plant involved (Silva et al., 2014).

The hypothesis of the present study was that the traffic of the roller affects the density of the soil and the related compaction degree and reduces the crambe yield. Thus, the objective of this study was to evaluate the influence of compaction degree on crambe grain yield.

\section{Methodology}

The experiment was conducted in the experimental area of Faculdade Assis Gurgacz, Cascavel, PR, Brazil (72³9’ W, $24^{\circ} 62^{\prime} \mathrm{S}$, and $760 \mathrm{~m}$ above sea level). According to the Koppen classification, the climate of the region is Cfa, humid subtropical, with an average annual rainfall of $1620 \mathrm{~mm}$. The soil in the area was classified as a typical dystrophic red latosol, with a clayey to very clayey texture, basalt substrate, and smooth wavy relief (60\% clay, $32 \%$ silt, and $8 \%$ sand), according to Embrapa (2018). The chemical analysis indicated $\mathrm{pH} 5.6$ in $\mathrm{CaCl} 2\left(0.01 \mathrm{~mol} \mathrm{~L}^{-1}\right) ; 49 \mathrm{~g} \mathrm{~kg}^{-1}$ organic matter; $22 \mathrm{mg} \mathrm{kg}{ }^{-1} \mathrm{P}$ (Mehlich-1); 1.6 cmolc kg-1 of $\mathrm{K}^{+} ; 6.8$ cmolc kg $\mathrm{kg}^{-1}$ of $\mathrm{Ca}^{2+} ; 2.9$ cmolc kg-1 of $\mathrm{Mg}^{2+} ; 10.3 \mathrm{cmolc} \mathrm{kg}^{-1}$ of cation exchange capacity (CEC); and 64\% saturation basis. The physical characteristics of the soil before the experiment indicated a density of $1.1 \mathrm{Mg} \mathrm{m}^{-3}$, microporosity of $16.1 \%$, and macroporosity of $40.8 \%$. The experimental area was cultivated using a NT system 
with soybean, corn, and wheat crop rotations for 20 years.

The experimental design was a strip-block with four repetitions. In areas using the roller compactor (one pass, three passes, and five passes), the dimensions of the strips were $7 \times 100 \mathrm{~m}$, and in the region with natural compaction using the NT system ( 0 passes), the strips were $79 \times 100 \mathrm{~m}$. Soil compaction was performed with a Müller RTG2 roller compactor with a mass of $5 \mathrm{Mg}$ and a vibrating device, with a pressing wheel of $1.20 \mathrm{~m}$ wide and $1.35 \mathrm{~m}$ in diameter, and a guide wheel of 1.20 $\mathrm{m}$ long and $0.96 \mathrm{~m}$ in diameter. Three compaction states were established by one, three, and five passes of the roller over 100 $\mathrm{m}$ long and $7 \mathrm{~m}$ wide strips. The roller was not used in the remaining area. The treatments were configured as follows: no passes (0P) (state of natural compaction of the NT system), one pass (1P), three passes (3P), and five passes (5P).

The gravimetric soil water content values at the moment the roller passed were determined using the drying oven method (Embrapa, 1997) and are listed in Table 1. Forty random points were selected in the experimental area, and 10 sample points for each compaction state were georeferenced using a Garmin GPS, model 60CSx. Before sowing and after the crambe harvest, undisturbed soil samples were collected, using cylinders $0.05 \mathrm{~m}$ high and $0.05 \mathrm{~m}$ in diameter in the $0-0.1$ and $0.1-0.2$ $\mathrm{m}$ layers for density determination, following the volumetric ring method, described by Embrapa (1997).

Table 1. Soil water content $\left(\mathrm{kg} \mathrm{kg}^{-1}\right)$ for compaction in the $0-01$ and $0.1-0.2 \mathrm{~m}$ layers.

\begin{tabular}{lcc}
\hline Roller passes & \multicolumn{2}{c}{ Layer } \\
\cline { 2 - 3 } & $0-0.1 \mathrm{~m}$ & $0.1-0.2 \mathrm{~m}$ \\
\hline OP & 0.355 & 0.389 \\
1P & 0.350 & 0.370 \\
3P & 0.348 & 0.367 \\
5P & 0.326 & 0.357 \\
\hline
\end{tabular}

Source: Authors.

The compaction degree $(\mathrm{CD})$ was estimated using the equation: $\mathrm{CD}=(\mathrm{Ds} / \mathrm{DsIHO}) \times 100$, where $\mathrm{Ds}$ is the density of the soil and DsIHO is the critical density established from the optimal water range (DsIHO $=0.00078 \times \%$ clay +1.83803 ) according to Reichert et al. (2009).

The first and second cultivations of the crambe crop occurred in 2018 and 2019, respectively. For seeding, a continuous flow seeder-fertilizer was used (model PST3 TATU/Marchesan®). The seed used was from the cultivar FMS Brilhante, which was seeded with $0.3 \mathrm{~m}$ between rows, a sowing depth of $0.03 \mathrm{~m}$, and a density of $12 \mathrm{~kg} \mathrm{ha}^{-1}$.

The crambe was harvested from an area of $4 \mathrm{~m} 2$ at each sampling point with 10 samples. The results of the crambe grain yield were expressed in $\mathrm{Mg} \mathrm{ha}^{-1}$, with the moisture content corrected to 13\%.

The data were tested for the assumptions of analysis of variance (normality). When these requirements were met, the data were subjected to an analysis of variance $(\mathrm{p}<0.05)$ using the statistical software Sisvar® (Statistical Analysis Software, UFLa, Lavras, MG, Brazil). The means were compared using Tukey's test, and statistical significance was set at $\mathrm{p}<0.05$.

\section{Results and Discussion}

Compacting the soil with a roller linearly increased $(\mathrm{p}<0.05)$ the density values compared to the natural state of the NT system (0P) characterizing soil compaction. Roller utilization increased soil bulk density from 0.98 to $1.24 \mathrm{Mg} \mathrm{m}^{-3}$ in the $0-0.1 \mathrm{~m}$ layer and 1.03 to $1.15 \mathrm{Mg} \mathrm{m}^{-3}$ in the $0.1-0.2 \mathrm{~m}$ layer (Figures $1 \mathrm{~A}$ and $\mathrm{C}$ ). Compaction caused by agricultural machines and implements intensified in the $0-0.1$ and $0.1-0.2 \mathrm{~m}$ layers, since soil tillage occurs only in the sowing line in the 
NT system (Bonini et al., 2009). A high compaction degree reduces soil porosity and aeration, increasing soil density and resistance to penetration. The greatest state of compaction in a NT system occurs at a depth of approximately $0.10 \mathrm{~m}$, mainly due to the confinement of pressures imposed by machine traffic (Genro Junior et al., 2004; Collares et al., 2006; Bonini et al., 2011) as observed in the present study (Figure 1A). Despite the benefits of the NT method, compaction challenges are common, especially in clayey soils (Nunes et al., 2015; Blanco-Canqui and Ruis, 2018).

Figure 1. Soil bulk density in the 0-0.1 $\mathrm{m}(\mathrm{A})$ and 0.1-0.2 $\mathrm{m}(\mathrm{C})$ layer and compaction degree in the 0-0.1 $\mathrm{m}(\mathrm{B})$ and $0.1-0.2 \mathrm{~m}$ (D) layer affected by soil compaction with machine passes (P).** Significant at 1\%; Error bars indicate the standard deviation.
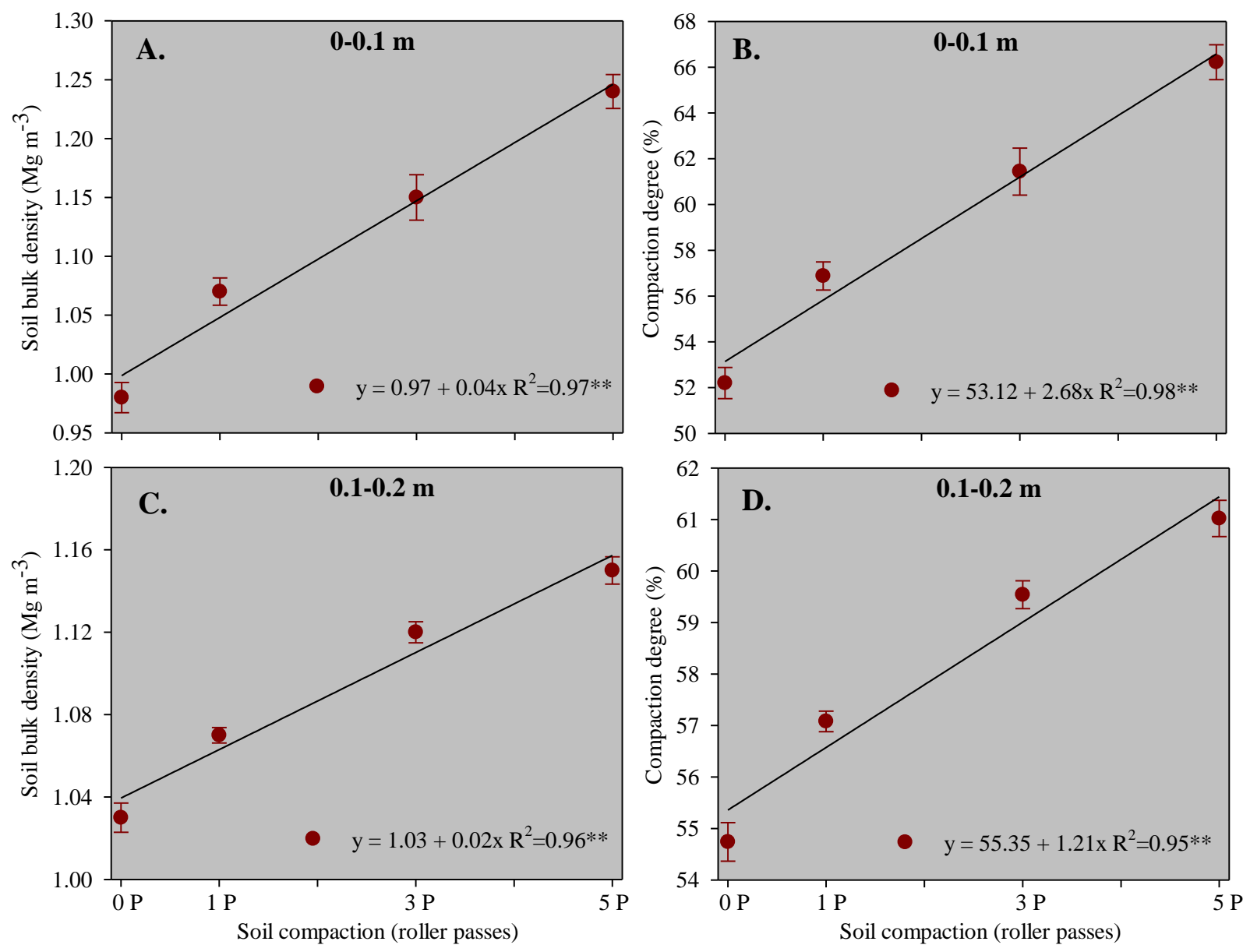

Source: Authors.

The passes of the roller linearly increased the compaction degree $(\mathrm{p}<0.05)$ in the $0-0.1$ and $0.1-0.2 \mathrm{~m}$ layers (Figures $1 \mathrm{~A}$ and $\mathrm{C}$ ) from $52 \%$ to $66 \%$ in the $0-0.1 \mathrm{~m}$ layer and from $54 \%$ to $61 \%$ in the $0.1-0.2 \mathrm{~m}$ layer from 0 to 5 passes (Figures $1 \mathrm{~B}$ and D). Soil compaction reduced the yield of crambe grains $(\mathrm{p}<0.05)$ by $41 \%$ and $9 \%$ in the first and second year, respectively, compared to NT without additional compaction (Figure 2A and B). 
Figure 2. Crambe grain yield affected by soil compaction with machine passes $(\mathrm{P}) .{ }^{* *}$ Significant at $1 \%$; Error bars indicate the standard deviation.
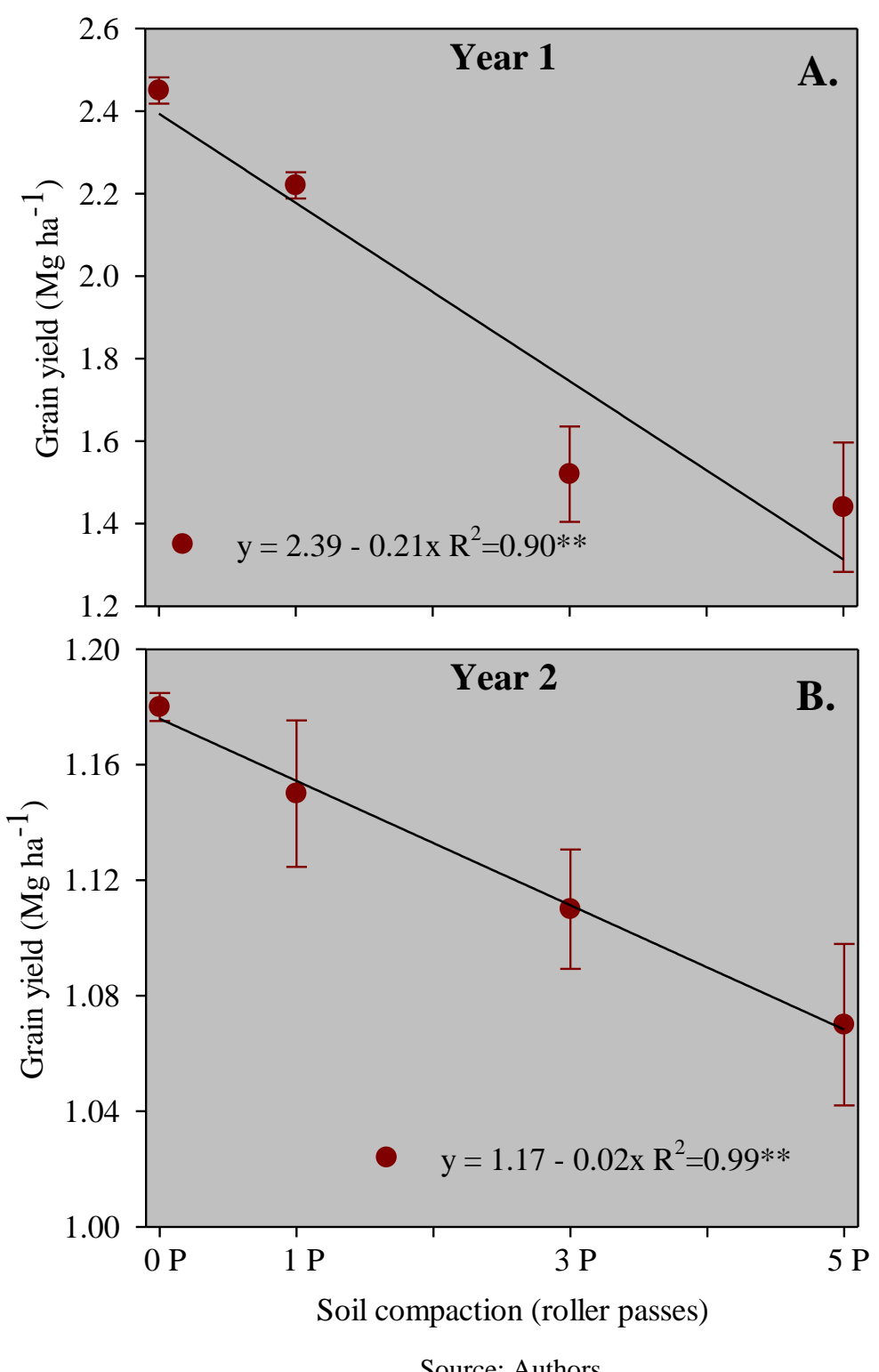

The effects of soil compaction on crop growth depend on the farm machinery load, soil type, and crop system (Toliver et al., 2011; Soane et al., 2012). Compaction effects on root and crop growth have been extensively reported (Rosolem et al., 2002; Sarto et al., 2018; Bassegio et al., 2018). Water and nutrient availability are limited for crop roots in compacted soil (Sadras et al., 2005; Ahmad et al., 2009), thereby restricting the elongation ability of roots, which completely ceases at a soil pressure of $2 \mathrm{MPa}$ (Bengough et al., 2006). The restricted root growth, in turn, could affect crop seeding (Jordan et al., 2003), leaf expansion, stomatal conductance (Lipiec et al., 2003), product yield, and quality (Hassan et al., 2007; Chen and Weil, 2010). However, soil compaction has positive effects on crop growth. Moderate soil compaction can increase the root-soil contact, allowing the root to extract adequate resources (Atkinson et al., 2009; Bouwman et al., 2020). The Essa advantage effect suggests that there is an optimal degree of compaction for crop growth in different environments (Arvidsson et al., 2014). 
Despite the effect of compaction, the crambe grain yield (1.4 to $\left.2.5 \mathrm{Mg} \mathrm{ha}^{-1}\right)$ was within the expectations for southern Brazil (Cattanêo et al., 2016; Marins et al., 2018). When the compaction degree was greater than or equal to 53\%, we observed a reduction in the grain yield of the crambe. Bonini et al. (2011) found that the reduction in the wheat grain yield with five passes of a roller compactor was due to changes in the structural state of the soil, mainly increased density $\left(1.39 \mathrm{Mg} \mathrm{m}^{-3}\right)$ and reduced volume of macropores $\left(0.02 \mathrm{dm}^{-3}\right)$ in the $0.1-0.2 \mathrm{~m}$ layer. Increased soil density is an important attribute that defines resistance to penetration, water infiltration, and gas exchange in the soil (Secco et al., 2009; Bonini et al., 2011).

\section{Conclusion}

Compaction with a roller increased the density of the soil and the compaction degree and reduced the crambe grain yield. When the compaction degree reached 53\%, the crambe grain yield was reduced. Soil compaction decreased the yield of crambe by $41 \%$ and $9 \%$ in the first and second years, respectively, compared to NT without additional compaction; therefore, crambe is not suitable crop for compacted soils.

\section{References}

Ahmad, N., Hassan, F. U., \& Belford, R. K. (2009). Effect of soil compaction in the sub-humid cropping environment in Pakistan on uptake of NPK and grain yield in wheat (Triticum aestivum): I. Compaction. Field Crops Research, 110(1), 54-60.

Andognini, J., Albuquerque, J. A., Warmling, M. I., Teles, J. S., \& Silva, G. B. D. (2020). Soil compaction effect on black oat yield in Santa Catarina, Brazil. Revista Brasileira de Ciência do Solo, 44.

Arvidsson, J., Etana, A., \& Rydberg, T. (2014). Crop yield in Swedish experiments with shallow tillage and no-tillage 1983-2012. European journal of agronomy, 52, 307-315.

Atkinson, B. S., Sparkes, D. L., \& Mooney, S. J. (2009). The impact of soil structure on the establishment of winter wheat (Triticum aestivum). European Journal of Agronomy, 30(4), 243-257.

Bassegio, D., Sarto, M. V. M., Rosolem, C. A., \& Sarto, J. R. W. (2018). Guar root and shoot growth as affected by soil compaction. Pesquisa Agropecuária Tropical, 48, 163-169.

Bengough, A. G., \& Young, I. M. (1993). Root elongation of seedling peas through layered soil of different penetration resistances. Plant and soil, 149(1), $129-139$.

Bergamin, A. C., Vitorino, A. C. T., Franchini, J. C., Souza, C. M. A. D., \& Souza, F. R. D. (2010). Compactação em um Latossolo Vermelho distroférrico e suas relações com o crescimento radicular do milho. Revista Brasileira de Ciência do Solo, 34(3), 681-691.

Betioli Júnior, E., Moreira, W. H., Tormena, C. A., Ferreira, C. J. B., Silva, Á. P. D., \& Giarola, N. F. B. (2012). Intervalo hídrico ótimo e grau de compactação de um Latossolo Vermelho após 30 anos sob plantio direto. Revista Brasileira de Ciência do Solo, $36(3), 971-982$.

Blanco-Canqui, H., \& Ruis, S. J. (2018). No-tillage and soil physical environment. Geoderma, 326, 164-200.

Bonini, A. K., Secco, D., Santos, R. F., Reinert, D. J., \& Reichert, J. M. (2011). Atributos físico-hídricos e produtividade de trigo em um Latossolo sob estados de compactação. Ciência Rural, 41, 1543-1548.

Bouwman, L. A., \& Arts, W. B. M. (2000). Effects of soil compaction on the relationships between nematodes, grass production and soil physical properties. Applied Soil Ecology, 14(3), 213-222.

Carter, M. R. (1990). Relative measures of soil bulk density to characterize compaction in tillage studies on fine sandy loams. Canadian Journal of Soil Science, 70(3), 425-433.

Castro, M. B. S., Secco, D., de Marins, A. C., Bassegio, D., de Souza, S. N. M., \& Junior, L. A. Z. (2021). Propriedades físicas do solo e produtividade de grãos de milho cultivo após espécies de cobertura. Research, Society and Development, 10(16), e220101623786-e220101623786.

Cattanêo, A. J., Stangarlin, J. R., Bassegio, D., \& Santos, R. F. (2016). Crambe affected by biological and chemical seed treatments. Bragantia, 75 , $292-298$.

Collares, G. L., Reinert, D. J., Reichert, J. M., \& Kaiser, D. R. (2008). Compactação de um Latossolo induzida pelo tráfego de máquinas e sua relação com o crescimento e produtividade de feijão e trigo. Revista Brasileira de Ciência do Solo, 32(3), 933-942.

Embrapa (1997). Empresa Brasileira de Pesquisa Agropecuária. Manual de métodos de análise de solo.

Embrapa (2013). Empresa Brasileira de Pesquisa Agropecuária. Sistema brasileiro de classificação de solos. Centro Nacional de Pesquisa de Solos: Rio de Janeiro. 
Genro Junior, S. A., Reinert, D. J., Reichert, J. M., \& Albuquerque, J. A. (2009). Atributos físicos de um Latossolo Vermelho e produtividade de culturas cultivadas em sucessão e rotação. Ciência Rural, 39(1), 65-73.

Håkansson, I. (1990). A method for characterizing the state of compactness of the plough layer. Soil and tillage research, 16(1-2), 105-120.

Håkansson, I., \& Lipiec, J. (2000). A review of the usefulness of relative bulk density values in studies of soil structure and compaction. Soil and Tillage Research, 53(2), 71-85.

Hamza, M. A., \& Anderson, W. K. (2005). Soil compaction in cropping systems: A review of the nature, causes and possible solutions. Soil and tillage research, 82(2), 121-145.

Hassan, F. U., Ahmad, M., Ahmad, N., \& Abbasi, M. K. (2007). Effects of subsoil compaction on yield and yield attributes of wheat in the sub-humid region of Pakistan. Soil and Tillage Research, 96(1-2), 361-366.

Lindstron, M., \& Voorhees, W. (1994). Response of temperate crops to soil compaction. Soane, BD \& van Ouwerkerk, C. Soil compaction in crop production. London, Elsevier, 265-286.

Lipiec, J., \& Hatano, R. (2003). Quantification of compaction effects on soil physical properties and crop growth. Geoderma, 116(1-2), 107-136.

Marins, A. C., Reichert, J. M., Secco, D., Rosa, H. A., \& Veloso, G. (2018). Crambe grain yield and oil content affected by spatial variability in soil physical properties. Renewable and Sustainable Energy Reviews, 81, 464-472.

Mueller, L., Schindler, U., Mirschel, W., Shepherd, T. G., Ball, B. C., Helming, K., ... \& Wiggering, H. (2011). Assessing the productivity function of soils. In Sustainable Agriculture Volume 2 (pp. 743-760). Springer, Dordrecht.

Nunes, M. R., Denardin, J. E., Pauletto, E. A., Faganello, A., \& Pinto, L. F. S. (2015). Mitigation of clayey soil compaction managed under no-tillage. Soil and Tillage Research, 148, 119-126.

Peixoto, D. S., Silva, B. M., de Oliveira, G. C., Moreira, S. G., da Silva, F., \& Curi, N. (2019). A soil compaction diagnosis method for occasional tillage recommendation under continuous no tillage system in Brazil. Soil and Tillage Research, 194, 104307.

Queiroz-Voltan, R. B., Nogueira, S. D. S. S., \& Miranda, M. A. C. D. (2000). Aspectos da estrutura da raiz e do desenvolvimento de plantas de soja em solos compactados. Pesquisa Agropecuária Brasileira, 35(5), 929-938.

Reichert, J. M., Suzuki, L. E. A. S., Reinert, D. J., Horn, R., \& Håkansson, I. (2009). Reference bulk density and critical degree-of-compactness for no-till crop production in subtropical highly weathered soils. Soil and Tillage Research, 102(2), 242-254.

Sadras, V. O., O’Leary, G. J., \& Roget, D. K. (2005). Crop responses to compacted soil: capture and efficiency in the use of water and radiation. Field Crops Research, 91(2-3), 131-148.

Santos, G. A. D., Dias Junior, M. D. S., Guimarães, P. T. G., \& Furtini Neto, A. E. (2005). Diferentes graus de compactação e fornecimento de fósforo influenciando no crescimento de plantas de milho (Zea mays L.) cultivadas em solos distintos. Ciência e Agrotecnologia, $29,740-752$.

Secco, D., Reinert, D. J., Reichert, J. M., \& Silva, V. R. D. (2009). Atributos físicos e rendimento de grãos de trigo, soja e milho em dois Latossolos compactados e escarificados. Ciência Rural, 39(1), 58-64.

Silva, F. R. D., Albuquerque, J. A., \& Costa, A. D. (2014). Crescimento inicial da cultura da soja em Latossolo Bruno com diferentes graus de compactação. Revista Brasileira de Ciência do Solo, 38, 1731-1739.

Soane, B. D., Ball, B. C., Arvidsson, J., Basch, G., Moreno, F., \& Roger-Estrade, J. (2012). No-till in northern, western and south-western Europe: A review of problems and opportunities for crop production and the environment. Soil and Tillage Research, 118, 66-87.

Suzuki, L. E. A. S., Reichert, J. M., Reinert, D. J., \& Lima, C. L. R. D. (2007). Grau de compactação, propriedades físicas e rendimento de culturas em Latossolo e Argissolo. Pesquisa Agropecuária Brasileira, 42, 1159-1167.

Toliver, D. K., Larson, J. A., Roberts, R. K., English, B. C., De La Torre Ugarte, D. G., \& West, T. O. (2012). Effects of no-till on yields as influenced by crop and environmental factors. Agronomy journal, 104(2), 530-541.

Tokura, L. K., Secco, D., Júnior, L. A. Z., Siqueira, J. A. C., Alovisi, A. M. T., Barison, A., \& Zin, Z. (2021). Use of cover crops in Oxisol and its effects on yield and soybean oil content. Research, Society and Development, 10(12), e353101220514-e353101220514. 